\title{
Atopic Objects: The Afterlives of Gold Teeth Stolen from Holocaust Dead
}

\begin{tabular}{|r|l|}
\hline Journal: & Journal Of Material Culture \\
\hline Manuscript ID & MCU-19-0099.R1 \\
\hline Keywords: & Holocaust, atopia, materiality, grave robbery, economic violence \\
\hline & $\begin{array}{l}\text { Transfers of property are an integral part of armed conflicts and } \\
\text { instances of mass political violence. Not just the state and the military, } \\
\text { but also civilians confiscate, dispossess, loot, and redistribute wealth } \\
\text { across ethnic, national, class, or religious lines, in the process reenacting } \\
\text { and sustaining the boundaries of othering and belonging that stand } \\
\text { behind the conflict. In this way, economic violence takes on an } \\
\text { essentially political dimension. Although to date rarely conceptualized as } \\
\text { such, even grave robbery perpetrated at the burial sites of a defeated } \\
\text { enemy or a member of othered minority constitutes a practice of alterity } \\
\text { and dehumanization. And while in the aftermath of violence this very fact } \\
\text { has the ability to invest things taken from mass graves with a } \\
\text { particularly disturbing potential, this article reflects on the practices and } \\
\text { affective dynamics surrounding objects of a distinctively unsettling } \\
\text { status: golden teeth and dental bridges in their ambivalent condition } \\
\text { between material objects (valuables) and bodily remains of the dead. } \\
\text { They are considered in this paper through the conceptual lens of 'atopic } \\
\text { objects', a notion designed to bring to the fore both the out-of-place } \\
\text { quality and the at once as-well-as/neither-nor character of those things, } \\
\text { suspended on the threshold between human remains and material } \\
\text { objects, private possessions and body parts of othered and violently } \\
\text { dispossessed people. In this article, I ask how this uneasy ontological } \\
\text { status is experienced, acted upon and negotiated by the new (and rarely } \\
\text { rightful) 'owners' and offer insight into the practical, affective, political } \\
\text { and also legal framings through which 'atopic objects' are being } \\
\text { constructed and reconstructed either as things or as body parts and, at } \\
\text { the cost of their unsettling quality, become embedded in the postwar } \\
\text { orders, both in the intimate order of the body and in the political- } \\
\text { economic order of the state. }\end{array}$ \\
\hline Abstractions \\
\hline
\end{tabular}

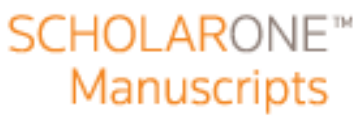




\section{Atopic Objects: The Afterlives of Gold Teeth Stolen from Holocaust Dead}

There are things whose trajectories are difficult to trace. They emerge fleetingly from the historical accounts and the stories surrounding mass violence only to disappear again, leaving little, or no, mark. The discursive existence of such objects, often revealed at the margins of historical narratives, and tainted with disturbance and indignation, is short-lived; only rarely does it coincide with their physical travels through the various material/cultural/political realms and regimes of value. Their fate is at best only partially or fragmentarily understood, the rest being left to an unsettling imagination and surmise: 'we' are aware that they are 'out there', that they circulate, and swap hands, undergo material transformations that perpetuate or obliterate their provenance, that they become embedded in new material, social and economic orders; they are domesticated and reused, their history and historical specificity eradicated. But the details, the actual how, why and to what effect of the process remain uncharted. From an analytical and ethical point of view, it is precisely this scarcity of data that renders these objects and their afterlives a salient topic of investigation. Whenever possible and however partial it might be, their trajectories necessitate inquiry in order to shed light on an underexplored dimension of mass violence and its aftereffects, both tangible and intangible.

This article seeks to trace and interpretively unpack the afterlives of several such objects. It examines the fates of gold teeth taken from the dead, and from body disposal pits, by the non-Jewish local populace in several areas of Eastern Europe, during and after the Holocaust. ${ }^{1}$ The paper focuses on two case studies pertaining to the afterlives of objects acquired through grave robbery in wartime Lithuania and postwar Poland. The first case revolves around a golden tooth dug up from a burial site in the immediate aftermath of a mass execution and thereafter sold to a private person, who, fully aware of its disturbing provenance, had it implanted in her own mouth. In the second case, dental bridges and gold mined after the war from a body disposal pit at the site of the former extermination camp swapped hands between grave robbers, police officers and other state functionaries, ultimately appearing in the Treasury of the state. Although different and reconstructed from distinct source material (oral history in the first instance and criminal trial records in the second), both stories offer an important insight into the practical, affective, political and legal framings through which objects stolen from mass graves are being constructed and reconstructed either as things or as body

\footnotetext{
${ }^{1}$ Following recent developments in the discursive field of Holocaust studies (Sendyka, 2019), I restrain from framing the locations of human remains resulting from the Holocaust as mass graves and construct them, instead, as body disposal pits. This is to acknowledge that to deny the victims the right to burial was an additional, posthumously dehumanizing, form of violence perpetrated by the Nazis.
} 
parts and, at the cost of their unsettling quality, become embedded in the postwar orders, both in the intimate order of the body and in the political-economic order of the state. Building upon the available source material, scarce though it is, the article asks about the material/affective/political dynamics surrounding looted dental gold. How do gold teeth stolen from the dead become incorporated into postwar or post-conflict orders and economies? How do they enter and travel through various regimes of meaning and worth? How are they experienced, interpreted, acted upon by their new and rarely rightful 'owners'? How do their afterlives speak to (and about) historical and cultural specificities?

Attending analytically to the trajectories of gold teeth beyond the immediate context of the robbery of the dead, the article also seeks to address a significant lack in the academic literature of theoretically informed approaches to the material/affective/political particularity of looted gold teeth and the trajectories they travel. Gold teeth differ, and resonate differently, from other objects looted from the Holocaust dead, and their transgressiveness is explored in the article through the notion of ontologically and epistemologically troubling atopic objects, suspended between material things and human remains of the dead. Against the renewed and constantly growing academic interest in material culture and the material legacies of the Holocaust (cf. for instance, Shallcross, 2011; Klinger, 2017; Benninga, 2018), gold teeth continue to generate an unease, even when they are mediated by archival documents and eyewitness accounts. All too often, this translates into their affectively and normatively charged (un)framing. When those scholars who do address the phenomena refer to cases of looted dental gold merely as moments of moral inadequacy, they forfeit interpretative exploration and occlude insight into the very frames and sensibilities that enable the circulation of these objects and ensure their continuous, if unobtrusive, presence. Cutting across empirical and theoretical realms, this article explores the dynamics that render the ties between objects and the violence through which they originated discernible and undone, thereby seeking to expose the cultural and political implications of this process, including for our understanding of the Holocaust and its aftereffects in Eastern Europe.

\section{Things Looted from the Dead}

The practice of scavenging from the bodies and graves of the dead during and following periods of armed conflict and political violence is a universal phenomenon, present across cultures and geographies. It adds yet another layer to the dynamics of political and economic violence of which confiscations, dispossession, looting and the transfer of wealth from one population to another are an integral part. Even more so for grave robbery that unfolds along 'racial', ethnic, 
national, religious, or class lines; here, it is the grave of a racialized subject, of an enemy combatant, of a member of an excluded minority, of the dehumanized Other, that is being looted. A growing body of research provides evidence of such practices in contexts as disparate as the colonial conquest, intimately linked to the greed-driven and 'scientific' looting of Aboriginal and Indigenous burial sites; the American Civil War; the Armenian genocide; the Spanish Civil War of 1936-9; the Second World War; and the Vietnam War, to name only a few (Fforde et al., 2002; Harrison, 2012; Renshaw, 2011; Wagner, 2015). While the commonality of the practice is well established, our knowledge and understanding of those objects looted from the dead and of their subsequent afterlives varies greatly depending on context. While the fates of things looted from some historically- and conflict-specific graves are known and well documented, others remain obscure. Often it is a temporal distance from the events and taboo-breaching practices (and sensitivities behind them) that first enables research.

An extensive record exists, for instance, of the objects that were stolen from the dead in the colonial period and for decades exhibited and deposited at various research institutions and museums in the Western Hemisphere. Only in the wake of debates (re)constructing their status as looted possessions of the dead, and not merely as objects of scientific inquiry and/or tokens of foreign cultures, did these objects begin to disappear from public spaces in order to be repatriated to descendant communities and/or subjected to critical provenience research (Förster et. al, 2018). Thanks to a study conducted by Harrison (2012), much more is now known about the different trajectories of the human remains and personal effects of the dead acquired through the practice of trophy-taking in modern war: their celebratory circulation as gifts, their exhibition as mementos during and in the immediate aftermath of armed conflict, and the unease (and amnesia) that increasingly builds around them with the passage of time. In her book on the Spanish Civil War, and in her contribution to this issue, Renshaw (2011) looks at the narratives of theft surrounding the looting of Republican graves. In this case, the trajectories of a few objects can be reconstructed through accounts provided by relatives of the dead: it was often through encounters with killers dressed in victims' clothes and personal effects that people learned of the death of a loved one. Such incidents were also a reminder of the perpetrators' uncontested power and impunity during and in the aftermath of the war. The openly displayed loot came to encode the continuity of violence and was experienced as such. Drawing from various historical and geographical contexts, these scholarly works map the overlapping and divergent trajectories of grave-robbery and scavenging from the dead, enabling their inceptive classification. Widespread at historical mausoleums and tombs, the practice - 
conditioned by the transient circumstances of war, violence and impunity - remains rife in relation to objects found on the unburied dead and is recurrent, though much less systematic, with regards to things buried in graves and to human remains themselves. When it comes to the gold teeth often violently extracted from the bodies of victim of the Holocaust, however, still not much is known.

The looting of the dead by local non-German and non-Jewish populations during and following the Holocaust in Eastern Europe was first subject to academic research in 2011, when Gross and Grudzińska Gross published Golden Harvest: Events at the Periphery of the Holocaust, first in Polish, then in English (2012). This was long after the Nazi dispossession of the victims of concentration and extermination camps, which had already been thoroughly covered by historians (Strzelecki, 1998; Perz, 2012). ${ }^{2}$ This inquiry followed, too, a pioneering engagement with the scale and scope of Polish involvement in the Holocaust, offered by Gross in Neighbours: The Destruction of Jewish Community in Jedwabne, Poland (2001). Neighbours challenged the common framing of those populations as 'bystanders' or 'witnesses' to the Holocaust, which portrays wartime violence as the sole responsibility of the Germans; it cast Poles as perpetrators. Golden Harvest, in turn, interpretively engaged with the plunder of Jewish property by non-Jewish Poles during the Second World War. Structured around a photograph of looters resting among human remains at the former extermination camp of Treblinka, the book's narrative addresses the fact that the Holocaust was from the outset a source of considerable material benefits for local non-Jewish communities, many of whom were complicit in its implementation and also profited from its outcomes. Exposing the extent to which the efficacy of Nazi expropriation and extermination policies were conditional on assistance from indigenous populations, Golden Harvest shows that non-Germans, too, actively participated $t$ in economic violence. Once the Nazis had taken what they could (Kreuzmüller and Zatlin, 2020), non-Jewish Poles continued with the practice of dispossession - robbing Jewish stores and houses after the outbreak of war, plundering vacated ghettos, taking possession of the property and personal valuables left behind by deported Jews, blackmailing, and committing economically motivated murder (Grabowski and Libionka, 2014). This process continued long into the postwar period, with substantial state involvement. By means of legal regulations which served to legitimize wartime property transfers, businesses and estates

\footnotetext{
2 The grave robberies performed by Poles at the sites of the former Nazi extermination camps were occasionally covered by the press in the postwar period. As recently argued by Buryła (2013), they have also found their way into Polish literature. What I am arguing here is that they have, nevertheless, remained relatively unknown to both the wider public and researchers, and still await an exhaustive interpretive engagement. This pertains, especially, to the trajectories of objects acquired through the practice.
} 
confiscated by the Nazis (and the Soviets) were taken over by the Polish state (Cieślińska Lobkowicz, 2014). Also private houses, buildings and land, defined by postwar law as "abandoned" or "ownerless", 3 were seized and nationalized, and objects were confiscated on behalf of the State Treasury. The restitution claimed by Jewish survivors in the early postwar years, although legally secured, was increasingly constrained by the authorities, and resented by the population at large (Skibińska, 2014; Krzyżanowski, 2014). Individual attempts at recovering property from private hands could be, and often were, life threatening (Gross 2007). Indeed, the issue of the restitution of Jewish property still remains contentious and largely unresolved in Poland: thus far no countrywide law has been introduced to enable it. While in 1997 a bill was passed to allow the reclamation of community ownership, both proposed reprivatization bills, in 2001 and 2017, effectively excluded the vast majority of Polish Jews from retrieving prewar properties. ${ }^{4}$ Since the war, then, the question of wartime and postwar economic violence, its outcomes and the ownership of Jewish things is charged as a source, and enactment, of anti-Jewish sentiment (Krawczyk 2012), and troubling as a subject of historical research.

Among the various forms of violent dispossession perpetrated by the Poles, the practice of looting corpses and body disposal pits was, it could be said, not the most severe - it did not result in death but merely benefited from it; perhaps for this reason, it is often dismissed by critics of Gross and Grudzińska Gross' book (Lis, 2011). But the norm and taboo-breaching nature of this practice renders it a powerful emblem not only of greed of the looters, but also of the dehumanization to which the Jewish Other, both living and dead, was subjected during the war and in its aftermath by non-Jewish Poles. In this context, the looting of the dead was not merely a gain-oriented act; it also constituted an exercise of alterity and dehumanization, enacting the boundaries of othering and exclusion (Dziuban, 2015).

Alongside a growing scholarly interest in the looting of the dead, the objects acquired through the practice have begun to (re)emerge - most often in the form of indignant and partial historical accounts mentioned earlier. They can be found, for instance, in the developing scholarship on local realities of the Holocaust in Eastern Europe, which documents the practice

\footnotetext{
3 This is how those properties were framed by several Decrees, passed between 1945-6, on formerly German properties which were abandoned and left behind. Every decree narrowed down the category of people eligible for individual claims to property (establishing, at the end, only direct heirs of the deceased as eligible for repatriation), and imposed various bureaucratic obstacles (high costs, short deadlines), rendering restitution de facto very unprofitable.

${ }^{4}$ The first reprivatization bill from 2001, which granted the right of restitution exclusively to previous owners holding Polish citizenship before the war and in 1999, was vetoed by the president, Andrzej Kwaśniewski (under pressure from the European Commission and NATO); the latest project of the bill on restitution of prewar properties, proposed in 2017, is equally exclusionary.
} 
of scavenging from the dead as it unfolded at the former camps, at the killing sites, and following individual deaths in Poland (Engelking/Grabowski, 2018) and in other Eastern European countries such as Lithuania (Vanagaite/Zuroff, 2017) or Ukraine (Desbois, 2008). Quoting from witness testimonies and archival documents, this research builds a small-scale and fragmentary archive of objects that were looted from the dead and the body disposal pits by local populations. The looting took place at the former killing centres during the war and immediately after liberation and it accompanied mass executions in liquidated ghettos and at Jewish cemeteries, the non-Jewish residents of towns and cities being ordered to bury the dead. Escapees from trains to extermination camps or from the ghettos were also killed and posthumously deprived of their possessions. The dead were robbed of their clothes, shoes, and watches. Their orifices were searched for hidden valuables. And many were violently deprived of their gold teeth.

This last practice figures prominently as the most disturbing and, perhaps also for this reason, often remains interpretively unframed - its gruesomeness is left to speak for itself. To quote some of the Polish accounts: in the town of Wysokie Litewskie, a primary school custodian attended to the site of execution of around fifteen people, "stripped the dead of their clothes and knocked out their teeth as well" (quoted in Engelking, 2018: 123). In Biłgoraj, after thirty Jews hiding in a basement of a house were hunted down and killed, a Pole who participated in the search "removed gold teeth from the corpses" (Skibińska, 2018: 314). After the extermination camp at Bełżec ceased to operate and the Nazis left, many representatives of the local population visited the site and "dug up single corpses, or sometimes mass graves containing several people [...]. They looked for golden teeth in the jaws." (Niedłużak, 1945: 185). In Bolesław, "the peasant selected by the Germans to the burial detail first knocked out [Mendel] Kogel's teeth with a shovel, and later buried his body in nearby woods." (Grabowki, 2013: 15) In another town, the members of the local fire brigade volunteered to work on burial details, hoping for an easy gain. An eyewitness recounted:

\footnotetext{
They fervently joined the work in order to strip the corpses of shoes and clothes. They also hoped to find money. Even dental gold was extracted with different tools. It is for this reason that, in Węgrów, they were nicknamed the 'dentists'. The 'dentists' would sell their goods through various intermediaries. When one of those intermediaries, who was a [postwar] officer of the court [...], was told that there was human blood on this gold, he responded: 'No, not at all, I thoroughly cleaned them myself.' (Quoted in Grabowski, 2018: $436)^{5}$
}

\footnotetext{
5 Similar burial/'dentist' details operated in other Polish towns. The involvement of the local fire brigades in the extermination and burial of the dead is meticulously documented by Grabowski $(2013,2018)$.
} 
The last quote, taken from the testimony deposited by Władysław Okulus at the Warsaw Jewish Historical Institute (ŻIH, 301/60430), is left interpretively unexplored by Grabowski. Yet it offers an initial glimpse into the source of unease so easily detectable in historical research surrounding the practice of robbing the dead of their gold teeth. The metaphorical reference to "human blood", taken literally by the 'intermediary' (probably responsible for recasting the gold and selling it on), establishes gold teeth as distinct from other things looted from the dead - a distinction effectively undone by the grave robbers themselves. Unlike watches or clothes, gold teeth are an integral part of the bodies of the dead and are, therefore, figuratively - and, indeed, often literally - 'bloodstained'. Until they are melted and recast, their shape and structure bear traces of their provenance as prosthetic human body parts, sometimes also of the violence through which they were acquired. And it is precisely this ambivalent ontological condition of dental gold, somewhere between material object and bodily remains of the dead, and its resulting troubling ethical and epistemic status, that I explore in this paper. I do so through the conceptual lens of atopic objects, a framing that will be explained and developed below. Following the trajectories of several gold teeth beyond the context of their immediate seizure from the dead, I ask if and how this atopic character translates into their afterlives and material journeys. Do these afterlives differ from those of other objects stolen from the dead during and in the aftermath of the Holocaust? How is the unsettling status of gold teeth being done or undone, negotiated and acted upon? What are the cultural, ethical and political implications of this process?

\section{Atopic Objects: Things Ontologically In-Between}

The concept of atopia was introduced by Plato in his dialogues to describe Socrates (1997: 117b). Socrates was atopic because he simultaneously belonged and did not belong to the polis, he did not fit into established notions of ordinariness and 'normalcy'; he was disturbing, excessive and unsettling. The ancient Greek word is etymologically derived from a privative, a negation of topos. A 'place' and a 'discourse', it refers back to the out-of-placeness of a person or a thing, to their unthinkability or unintelligibility, to their position outside of the discursive/normative order; but also to their role as the point from which the order of a discourse takes its root and, paradoxically, from which it begins to crumble and dissolve (Dziuban, 2009). In contemporary cultural theory, the semantic field of atopia encompasses a further set of meanings. The atopic stands for the unfamiliar and uncanny, it names the unexpected, absurd, and alien; it conveys the quality of being shocking and disquieting, of being unsettled and 
unsettling (Di Cesare, 2012; Barthes, 1977; Dziuban, 2009). I see atopic objects as epistemologically and ontologically troubling: their condition defies clear-cut categorization, they evade easy ordering, their ontological status remains ambivalent. The notion serves, therefore, to bring to the fore both the out-of-place quality and the at once as-well-as/neithernor character of objects, which invests them with the ability to disturb and cause unease. And it is through this conceptual frame that I read the phenomenon of stolen gold teeth: as objects with specific historicity, which were once part of the body, they remain suspended on the threshold between human remains and (valuable) material objects, both the private possessions and the body parts of othered and violently dispossessed people.

This atopic quality of gold teeth could, in fact, be seen to take its root in the ambivalent and liminal status of human remains, which also oscillate ontologically between the status of object/subject. Keenan and Weizman refer to human remains as "the kind of objects from which the trace of the subjects cannot be fully removed" (2012: 13). This notion is further developed by Fontein and Harries (2013), who capture this ontological duality in terms of the uneasy subjecthood/objecthood of dead bodies. "Being neither one nor quite the other", human remains, paradoxically, act and affect as both: as tokens of deferred human agency and as things in their idiosyncratic and specific physicality. ${ }^{6}$ This ontological in-betweenness, established and explored at the level of theory, is often experienced empirically as excessive and troubling. The urge arises to arrest or eliminate the uneasy ambivalence and the at once as-well-as/neithernor character of human remains, by constructing them either as objects or as subjects, at the cost of their inherent atopic quality. While they are not clearly defined as human remains, and their classifications vary across geographies and cultures, gold teeth, too, are subject to processes of hegemonic closure of meaning through "techniques of subjectification and objectification" (Fontein and Harries, 2013: 120). Their objecthood or subjecthood is established performatively and contextually as they travel through various regimes of meaning and value (Wagner, 2014). In this way, too, their atopic quality is obscured.

\footnotetext{
${ }^{6}$ An avenue further strengthening the notion of gold teeth as body parts can be derived from studies on bodily integrity as developed in Grosz's writing on prosthetic objects (2005) or Haraway's conceptualizations of prosthesis (1999). For both, subjectivity and bodily integrity are extended to include artificially, technologically or culturally acquired objects considered not an appendage but a constitutive element of the body, both of which are invariably transformed by their interaction. While Grosz and Haraway expand their analyses to include machines and technologies, social and architectural spaces and other living beings to radically destabilize the nature-culture divide (and that of inside/outside, human/inhuman) and to call for techno-hybridity, a gold tooth as a prosthetic body part replacing and restoring the function of a missing organ literalizes the concept of prosthesis. It is an indispensable and integral part of the body and, as such, blurs the division between natural and artificial organs, complicating - rendering atopic - bodily boundaries.
} 
In her publication on the Peruvian mass graves, Delacroix (2017) tells the story of an indigenous girl who recovered a gold tooth from the mouth of her murdered relative, with the aim of providing a proper burial. In doing so, the girl performatively established a distinction between objecthood/subjecthood of the thing as fixed. A 2018 FBI investigation into the practices of a Colorado mortuary home, whose owner had been accused of pulling gold teeth from corpses and selling them for personal profit, suggested, in turn, that the issue is not a simple one. From a legal point of view, the trade in such objects was considered permissible; but the extensive publicity and immediate outcry surrounding the case shows how ethically charged the subject remains, and points to the need to revisit, time and again, the question of what is considered permissible and impermissible, thinkable and unthinkable with respect to former gold body parts (Woods, 2018). Similarly, the subject/object status of gold teeth might be reasserted or undone by religious framing. The rabbinical authorities supervising archaeological research at Holocaust sites often - but not always - request "that prosthetic body parts, teeth, fillings and hair are treated the same as bones or soft tissue in terms of their handling and interment" (Sturdy Colls, 2018: 39). Also in the context of Holocaust-related grave robberies, the liminality of gold teeth has been a subject of (re)negotiation and (often temporary) arrest as these objects moved from the immediate context of the grave to and through other physical/normative/political realms, where they were shaped, among other things, by the legal, cultural and religious prohibition against the desecration of corpses and burial sites - a practice from which they obviously originated ${ }^{7}-$ by the persistent othering of and violence against the Jew ${ }^{8}$ and by the uneasy legal status of Jewish properties, the teeth included.

\section{Arrested Atopicity}

One such journey is documented in criminal trial records from 1960 and pertains to the former Nazi extermination camp in Sobibór, Poland. In 1942-3, around 200,000 Jews were exterminated in gas chambers at the site, their bodies cremated and disposed of in the pits. Immediately after the camp ceased to operate, the landscape was extensively scavenged: the

\footnotetext{
7 Under prewar Polish law, grave robbery carried severe penalties. In the "Decree on Crimes Particularly Dangerous during the Reconstruction of the State," passed on 13 June 1946, the communist authorities increased the maximum sentence for desecrating graves from two years to five or, in the case of particularly aggravating circumstances, to ten years of imprisonment. Art. 26, 27, Dziennik Ustaw z dnia 12.07.1946. Nr 30, poz. 192.

8 This violence, I argue, does not exhaust but, indeed, significantly adds to the atopicity of the gold teeth on an ethical and political plane. Gold teeth not acquired through grave robbery also carry liminality. For instance, it was a tooth extracted voluntarily by a person that materialized into a ring for the famous rescuer Oskar Schindler, bearing the inscription "He who saves a single life saves the world entire" (I am very grateful to Jay Winter for reminding me about this).
} 
residents of surrounding villages repeatedly visited the site, opened the graves in search of valuables and gold, dug in the ground and sifted through the ashes (Dziuban, 2015). The corpses had been meticulously searched when the camp was still operational, and gold teeth were systematically pulled out from the corpses and collected by the Nazis, or put into circulation outside the confines of the camp as currency by the camp guards (Rusiniak, 2008). Nonetheless, there exists enough empirical evidence to support the claim that searches carried out by local people developed into a largely normalized social practice (Gross and Grudzińska Gross 2012) and produced results, as much in Sobibor as at other sites of former extermination camps in Poland.

This evidence can be drawn from police and court records of cases of people who were caught red-handed and others who had bought up and traded in dental gold. Further evidence has been uncovered by researchers working on the afterlives of Auschwitz-Birkenau, Treblinka, or Bełżec (Zawodna, 2011; Rusiniak, 2008; the Author 2015; 2016; forthcoming) - from indignant press coverage addressing the scale and scope of the practice, its widespread character and virtual 'normalisation' in the communities around the camps, ${ }^{9}$ and from a (still underesearched and undertheorized) corpus of testimonies, collected by the memorials established at the former extermination centres (cf. BMM), or acquired through investigative journalism (Olszewski and Litka, 2011; Reszka, 2019). These include testimonies of Poles who (they claim) merely witnessed, or indeed participated in the lootings, and who testify to the mass character and durability of the practice, which at once resulted in and enacted the dehumanization of the remains of the Jewish Other and the objectification of the atopic things, the gold teeth, into mere items of financial gain.

The stories told in these reports are disturbing: the former extermination camps were systematically searched by people equipped with spades and sieves; the areas were divided among groups, sometimes families, rivalling for profit; it not was not uncommon that, in order to avoid capture by the police, the looters would transfer human remains en masse to the nearby woods, houses, barns, and examine them there; men, women, children would participate in the searches hand in hand; in some cases, armed gangs would protect the sites from the intervention of law enforcement agencies (Rusiniak, 2008; Zawodna, 2011; Olszewski and Litka, 2011; Jan, 2014). The gold teeth were sold and bought, melted and recast to be traded off in nearby urban centres (Sztandar Ludu, 1946; Dziuban, 2015). The looting continued deep into the postwar

\footnotetext{
${ }^{9}$ An extreme example of this normalization is described in a 1946 article in Sztandar Ludu: a land owner from a village near Treblinka made a fortune on valuables and dental gold that he and his wife bought from local children digging at the camp, selling it in Warsaw (Sztandar Ludu, 1946). I delve in more detail into the social context and cultural sensitivities which enabled this normalisation in Author $(2015 ; 2016$; 2019).
} 
period, resulting in few arrests, and significantly boosting local economies, a fact evidenced by recent research (Charnysh and Finkel, 2017). Yet very little is known about the ways in which dental gold appropriated at the sites was 'processed', how it was subjected to circulation and exchange, experienced and acted upon. The documents from the 1960 investigation and trial constitute, therefore, a very rare source material that allows us to trace the trajectories and afterlives of gold teeth looted from the Holocaust dead, and to better understand not only their practical but also their discursive and legal framings and reframings. ${ }^{10}$

The investigation, which resulted in a trial before the Provincial Court in Lublin, revolved around the actions of four men who, in the winter of 1960, were caught in the act at Sobibór by local policemen - digging in the pits, and sifting through the ashes in search of gold teeth hidden in the soil and among human remains. Teeth had also been extracted from corpses disposed of at the site (APL IVk 90/60 05/711: 2-19). The men were equipped with a shovel and a sieve, and a bag filled with burned human bones was also found at the former camp (probably with the intention of searching through it later on). It was a forester living in the vicinity of the site who informed the police about the practice, which he had witnessed on several occasions and tried to put an end to - but even gunshots fired in the air would not scare the looters off. The forester was able to identify some of the robbers as inhabitants of a nearby village and he confirmed their repeated presence at the site. One of them, arrested on site and tried by the Lublin court under Article 26 of the "Decree on crimes particularly dangerous during the reconstruction of the State", was sentenced to two years of imprisonment for desecration of the burial site and human remains of "victims of Hitlerite occupation" (APL 90/60 7/712: 1-76). The sentence was ratified by the Supreme Court in Warsaw.

During the trial, the accused admitted that he had been aware that he was looting a "Jewish burial ground" but did not realize that the site was "legally protected": it was not marked and he was not the first to search the area for gold and valuables (APL 90/60 7/712: 35). ${ }^{11}$ The man's (surprised) justification and belated realization that a "Jewish burial ground" could be subject to the same (legal and ethical) rules as non-Jewish graves, and that the terrain

\footnotetext{
${ }^{10} \mathrm{I}$ am well aware of the limitations resulting from work with trial records, especially those originating from the state socialist period, and dealing with the Holocaust, as sole historical sources: they are selective, partial and biased. The statements and testimonies which they contain, too, should be considered from a critical standpoint due to the context in which they were acquired. I nonetheless acknowledge the fact that they provide a unique gaze into the role of gold teeth objects as evidence in court and their post-trial fate. As far as possible, I also complement and contextualize my analysis by drawing from oral history accounts, other archival documents, interviews I conducted, press coverage and historical studies.

11 Two other men, arrested later, were investigated by a prosecutor’s office in Włodawa. Following a change in privacy laws, I could not access the files documenting this investigation and trial proceedings. Their testimonies were, nevertheless, collected in the course of police investigations serving the evidentiary basis for the Lublin trial. Their accounts contain a similar justification: they did not recognise the problematic nature of the practice.
} 
was not a 'gold mine', or a source of profit, but a meadow filled with human remains, echoes the excuses offered by other looters interrogated in the immediate postwar period, and interviewed in the last decades by memorials and researchers. Responses such as "I didn't know that [it was] prohibited" (quoted in Rusiniak 2008: 32), and "everybody was looking for gold" (Jan, 2014) have been reiterated time and again. Performatively and interpretively undone as atopic (prosthetic) body parts, gold teeth were seized as a mere source of financial gain in a practice stripped of any moral evaluation by its immediate participants. This framing could be legitimized and strengthened, too, by local moral authorities, grounding it in the othering of the Jew, as was the case in a village near Treblinka where a priest encouraged the activity in the following terms: "Since these were Jewish graves, dental gold and jewellery should not be left lying in the soil." (quoted in Rusiniak, 2008: 32) This dehumanizing and objectifying frame surrounding the Jewish dead and their prosthetic body parts apparently remained uncontested for the looters involved in the Lublin trial, too. ${ }^{12}$ But, perhaps more importantly, the atopic quality of the golden teeth, as loot and body part, was a subject of negotiation, of making and undoing, during the court proceedings themselves: it was there that their liminal status was again arrested.

The trial was based on eyewitness accounts but also on material evidence secured during the investigation. It is for this reason that the gold teeth stolen from the dead found their way into the court archives. During the police roundup and arrest, ten pieces of dental gold were found on the man sentenced in Lublin. A further piece of evidence was collected in the course of the investigation: a dental bridge with several gold teeth. A couple of days after the arrest, the police arrived at the house of the two other suspects and confiscated the bridge - which had been found, allegedly, by the man who was tried in Lublin and then hidden in a cupboard (APL IVk 90/60 05/711: 14; 16). All confiscated teeth served as corpus delicti, material evidence, for the crime of profanation of human remains, framed by the judge as "particularly socially noxious" (APL IVk 90/60 05/712: 49).

The teeth were, therefore, constructed as body parts of the dead who fell victim to desecration: the police and the court performatively and discursively located them on both ends of the ontological subject/object divide, giving justice to their atopic quality. And yet, the material practices revolving and evolving around the gold teeth exposed this framing as shortlived and normatively superficial. The teeth were not exhibited during the trial and/or reburied

\footnotetext{
12 In a 2019 publication, based on interviews with the representatives of the local populace, both those who participated in the events and their descendants, who were fully aware of their relatives' involvement in the robberies, Paweł Reszka demonstrates that the practice has, in fact, still not been subject to delegitimization and condemnation in those local communities and is consequently normalized (Reszka, 2019).
} 
at Sobibór but, instead, deposited in the Lublin branch of the National Bank of Poland. Immediately after the passing of the sentence, as noted in the documentation, "the evidence in the case" (APL IVk 90/60 05/712: 76) was confiscated on behalf of the State Treasury. Without further ado, the gold teeth, (re)constructed as mere things or objects of material worth, become embedded in the economic order of the state.

In their trajectory from the mass graves of Sobibór to the Treasury of the Polish state, the teeth passed through several regimes of meaning and value in which their ontological status likewise became open to negotiation: subjectified and constructed as prosthetic body parts of Jewish victims of the Holocaust, then invested with evidentiary value, their unsettling quality of being both object/subjects was first enhanced but then arrested. Ultimately, the particular historicity and troubled ontological status of gold teeth as body parts of murdered Jews was denied in a logic uncannily resembling that which stood behind the grave robbery itself. Most probably melted and recast, they journey onwards.

\section{From Mouth to Mouth}

The gold teeth of the Jewish victims of the Holocaust have also circulated through less official channels and along routes that more closely and, perhaps also more disturbingly, adhere to their initial function as prosthetic body parts - from the mouths of the dead to the mouths of the living as dental gold, fillings, and crowns. It is virtually impossible to assess the scope and scale of this phenomenon. In their book on the Holocaust in Lithuania, Vanagaite and Zuroff (2017) quote from the testimony of a man who, as a member of a Lithuanian Auxiliary Police Battalion, was actively involved in the mass executions of Jews at the Seventh Fort of the Kaunas Fortress in the summer of 1941. He recounts:

\footnotetext{
'After the execution, I saw [Pranas] Matiukas [another Lithuanian perpetrator] carrying several teeth. He showed them to us himself, they were laying in his hand. I asked what did he need the teeth for, and he explained that he was a dental technician, and his wife was a dentist. I saw around four teeth in Matiukas' hand, they were cleaned and polished.' All in all, Matiukas took part in the executions of 18000 people. (Vanagaite and Zuroff, 2017: 108)
}

That gold teeth were collected for reuse by local dentists - and that this practice extended beyond Kaunas and the surgery of Matiukas' wife, and, most probably, also beyond Lithuania - is confirmed by other historical records. According to an interview given in 2000 by a Lithuanian woman, Regina Prudnikowa, to the United States Holocaust Memorial Museum (USHMM: RG-50.473*0076), it was the local dentist that directed her clients to brokers in gold 
teeth, who would sell the loot they had often personally appropriated during and/or after executions. "In fact, many had them", asserted the interviewee, further contributing to the notion that trade in gold teeth for dental purposes was widespread and largely normalized. As must have been, too, the unsettled and unsettling status of the dental gold as former body parts of violently dispossessed people for those who had such teeth implanted in their mouth.

The interview with Prudnikowa offers an exceptional glimpse into how the practice could have been framed and justified by those benefiting from the availability and material circulation of gold teeth during and after the Holocaust. Prudnikowa herself, fully aware of their provenance, had a gold tooth and a crown looted from a corpse inserted in her mouth. ${ }^{13}$ The teeth originated from the executions of the 1000 Jewish residents of her hometown, the central Lithuanian village of Pliviskai, which took place in August and September of 1941. Lithuanians, too, participated in the killings. Prudnikowa's perspective on the collaboration and complicity of the locals in the genocidal violence and dispossession of the Jews is critical and constructed against the background of her memories of prewar "friendly coexistence" between the groups (delegitimized, however, by her own admission of her fear of working in a Jewish house based on a belief in the antisemitic myth of blood libel). She openly addresses the violence and violent dispossession perpetrated by the local non-Jewish population throughout the German occupation - the looting of Jewish stores, houses, corpses. It is in this context that she is asked by the interviewer, Nathan Beyrak: "Well, but the Jews - they must have had all kinds of golden rings." She responds, focusing on the execution: "Well yeah, they did. They probably were searched on the spot, because they were forced to undress until they were naked there, you see. Some of them, the richer ones, were naked and their teeth were extracted too. Even I bought one, because I needed an implant.” (USHMM: RG-50.473*0076)

This declaration catches the interviewer off guard. For the next ten minutes the interview focuses solely on the tooth - two teeth, in fact, but Beyrak is probably too unsettled to realize this. I quote more extensively from this conversation:

\author{
Nathan Beyrak: You bought a tooth! \\ Regina Prudnikowa: Yeah. Yes. \\ NB: Oh, so one could buy a tooth? \\ RP: Yes, a gold one. I don't know how much I paid, but not much.
}

\footnotetext{
${ }^{13}$ I first heard about the interview at a 2015 conference in Marseille, Material Traces of Mass Death: The Exhumed Object. It was mentioned in the presentation by Jane E. Klinger but left interpretively unpacked (Klinger, 2017: 100-101). Also Vanagaite and Zuroff quote from the interview but do not frame it in any way (2017: 274-275). In my recounting of it here, I insist that the interview does not 'speak for itself' and requires an interpretation.
} 
NB: Well, but you also have another person's tooth.

RP: Yeah, but I bought it [laughs]. I bought it for money.

NB: Well, but it was cheap, so that means you benefitted from it.

RP: Well, it was cheap, cheap. [...]

NB: Weren't you afraid to put that tooth in?

RP: Who knows. It was recast. They did not put the same one in. It was recast, you know, it was melted down and cast again.

NB: [pause] But still, I can imagine, the person from whom the tooth was taken, must have been tortured.

Prudnikowa agrees but refuses to acknowledge the connection between the suffering of the person killed and posthumously robbed of their teeth and their presence in her mouth. The interviewer pushes further:

NB: So that tooth-

RP: There is plenty of gold buried under ground in Pliviskai. ${ }^{14}$

\footnotetext{
${ }^{14}$ On the phantasm of the 'Jewish gold' as a powerful marker of antisemitism, see Buryła (2013).
} 
The interviewer gives up and moves on to another topic.

This conversation, as disturbing as it is fascinating, vividly conveys the disparity between the interviewer's and interviewee's perspective of what is considered permissible and impermissible, thinkable and unthinkable with respect to the gold tooth, a disparity grounded in the way both construct (or undo) the ontological status of the object/subject and its atopic quality. But it also provides an insight into the dynamics of objectification, in which the tooth is effectively stripped of its specific historicity and (reductively) made into a thing - one that allows for its unproblematic transfer from the intimate order of one body to that of another, where it becomes, again, a (prosthetic) body part of a living human being. The recasting of both teeth, their material transformation - the melting down in the case of the first, and separation from the human tissue in case of the other - is not enough to do the job, however, as much as Prudnikowa may attempt to put forward as a reasoned argument to suggest the opposite. In a similar vein, the normalization of the practice - further legitimized by a local dentist, who was clearly informed about the origin of the teeth and their brokers - underpins but does not complete the performative work done in order to arrest their atopic quality. The objectification unfolds, rather, when the tooth travels through yet another regime of meaning where it is constructed and acted upon as an object of material worth and monetary gain, as a commodity subjected to processes of circulation and exchange. The tooth was cheap, perhaps, but the bottom line is that she paid for it. The economic transaction constitutes a cut on the subject/object continuum.

This shift of meaning allows Prudnikowa to erase her own relationality to the subjects from whose death she (and others in the community) repeatedly benefitted - the othered and violently dispossessed Jews. It also enables her to maintain an unproblematic perception of her own positionality as an outsider to the violence towards, and the dehumanization of, the Jewish Other, who in her account is reduced merely to the "Jewish gold" (buried under the ground in Pliviskai). The reconfiguration of the tooth into an ordinary object of exchange neutralizes both its historical specificity as a (prosthetic) body part of a murdered human being and its troubled ontology as an atopic object/subject. This takes place regardless of Prudnikowa's knowledge about their provenance in violence, manifesting in the very materiality of the teeth (an actual tooth still coated in the crown). The line separating Prudnikowa from the 'real' perpetrators the killers who, after the executions, moved to Jewish houses and traded in "Jewish teeth" - is affixed to the notion that the ties between objects and the violence through which they originated can be undone when they are relocated to the realm of economic exchange. A cut, therefore, is also made through vulnerable social bonds, the bonds of empathy but also those of 
accountability, binding the victims with those who reaped benefits from their suffering and death. Those ties are effectively undone, the violence externalized and condemned; the economic transaction, structured around the mere economy of "need", is suspended in a moral and historical vacuum. "I needed an implant", Prudnikowa offers as an honest explanation, establishing her own purchase as ethically unproblematic, as if it did not carry any moral weight, as if it unfolds beyond or below its historical/ethical context, detached from events serving at its condition of possibility. And so, abstracted from the dense web of social relations, the teeth travel from the intimacy of one body to that of another, where they remain for decades, objectified, domesticated, own(ed), until the gaze of the camera, and of the interviewer, (re)constitutes them as disturbing evidence of the violent practice of robbing the dead, and of the enduring naturalization of its outcomes, as much material as ethical and political.

\section{Unsettling/Unsettled Ownership}

In the dedication to Golden Harvest, Gross and Grudzińska Gross quote a sentence from Wyka's As if Life: "A golden tooth ripped from a corpse will always bleed" (Gross and Grudzińska Gross, 2012). Even when taken metaphorically, the statement does not seem to hold. In fact, at the cost of their unsettling quality as subject/objects, the teeth looted from the Jewish dead and from their graves became embedded into postwar orders, both the intimate order of the body of individuals and the political-economic order of the state. As if there was no blood, no troubling out-of-placeness. And yet, even a fragmentary and partial investigation into the afterlives of these objects allows us to realize to what extent those orders were founded on genocidal violence and the dispossession of the Jewish other; a 'truth' that those orders disavow and refuse to recognize. This could be yet another way of conveying the atopic quality of things, this time in strictly political terms: as they expose the violence upon which the order has been predicated, they also expose the cracks in its foundation, acting as a reminder of its conditionality, contingence and fragility.

Revolving and evolving around the question of (un)rightful ownership and the various forms of violence through which it was acquired, this fragility/atopicity remains (potentially) proportional to the scale and scope of the dispossession of the Jews during the Holocaust and in its aftermath, and to the multitude of assets, objects, and properties embedded in the postwar material/social/economic (and bodily) orders across Eastern Europe. Nevertheless, it hardly ever finds its way into dominant discourses and sensitivities surrounding objects looted from the Jews, their travels and their continuous, unobtrusive presence. The naturalization, dehistoricisation and objectification of misappropriated goods, and their interpretive (un)framing 
by researchers, hold in check unsettling questions about the past but even more so about the footing of the current reality, about the status quo, about a present funded on exclusion, dispossession, and murder, about the vulnerability of ownership seized by violent means. When this fragility/atopicity sets in, it is articulated primarily in the sense of threat, present since the democratic transition of the 1980-90s, associated with the possibility of Jews returning to their Eastern European hometowns to reclaim their property. This sense of threat is rarely welcomed; rather, it feeds anti-Jewish sentiment, and almost inevitably results in the denial of the extent of economic violence that accompanied the Holocaust, perpetuating its continuity by other means (Krawczyk, 2014; Matyjaszek 2019). Instead of revising the frames and sensibilities that underpinned this (economic) violence, they are sustained - the fragility/atopicity of orders, and of objects, is, again, arrested and rendered invisible.

Here lies the pertinence, cultural, political but also ethical, of rendering ownership unsettled and unsettling, of restoring the atopic quality to things, sometimes even by letting them metaphorically and/or literally bleed. This involves (re)tracing their ties to the violence through which they originated, making their specific historicity discernible, following their travels in the past and into the present, whenever possible and however disturbing they may be, in order to understand and acknowledge their entanglements in the violence, its troubling continuity, and its tangible and intangible aftereffects. Vanagaite, whose words informed my work, formulated the meaning of this task in the following terms: "We need to ask where the gold in the teeth of our grandmothers came from. We have to ask questions - we owe it to the victims of the Holocaust.” (Quoted in Kaplan Sommer, 2018) But I think there is more at stake: 'we' owe it to 'ourselves', too.

\section{Archival Sources}

Archiwum Państwowe w Lublinie (APL)

988 Sąd Wojewódzki w Lublinie APL 90/60 7/711; APL 90/60 7/712

Archiwum Żydowskiego Instytutu Historycznego (்̇IH)

$301 / 60430$

Archiwum Muzeum Miejsca Pamięci w Bełżcu (BMM)

Libionka D (ed) (2013) Obóz zagłady w Bełżcu w relacjach ocalonych i zeznaniach polskich świadków. Lublin: Państwowe Muzeum na Majdanku.

Protokół przesłuchania świadka. Mieczysław Niedłużak. Nr R. 102/46. 17 October 1945, pp. 184-185.

United States Holocaust Memorial Museum (USHMM) 
Jan, 2014 - Interview conducted by the author

\section{Literature}

Benninga N (2018) The bricolage of death: Jewish possessions and the fashioning of the prisoner elite in Auschwitz-Birkenau, 1942-45. In: Auslander L and Zahara T (eds) Objects of War: The Material Culture of Conflict and Displacement. Ithaca and London: Cornell University Press.

Buryła S (2013) Tematy (nie)opisane. Kraków: Universitas.

Charnysh V and Finkel E (2017) The death camp Eldorado: political and economic effects of mass violence. American Political Science Review 111(4): 801-818.

Cieślińska Lobkowicz N (2014) Połowiczna restytucja. Los zaryzowanego mienia żydowskiego w powojennej Polsce. In: Grabowski J and Libionka D (eds) (2014) Klucze i kasa. O mieniu żydowskim $w$ Polsce pod okupacja niemiecka $i$ we wczesnych latach powojennych 1939-1950. Warszawa: Stowarzyszenie Centrum Badań nad Zagładą Żydów, pp. 439-492.

Delacroix D (2017) Ouvrir les fosses communes au Pérou : Envoyer au ciel' les objets trouvés ou les commercialiser? Les Cahiers Sirice 19(2): 105-122.

Desbois P (2008) Holocaust by Bullets: A Priest's Journey to Uncover the Truth Behind the Murder of 1.5 Million Jews. New York: Palgrave.

Di Cesare D (2012) Utopia of Understanding: Between Babel and Auschwitz. Albany: State University of New York Press.

Dziuban Z (2009) Obcość, bezdomność, utrata. Wymiary atopii wspótczesnego doświadczenia kulturowego. Poznań: Wydawnictwo WNS UAM.

Dziuban Z (2015) The politics of human remains at the 'peripheries of the Holocaust'. Dapim 29(3): 154-172.

Engelking B (2018) Powiat bielski. In: Engelking B and Grabowski J (eds) Dalej jest noc. Losy Żydów w wybranych powiatach okupowanej Polski. Warszawa: Stowarzyszenie Centrum Badań nad Zagładą Żydów, pp. 45-198.

Fforde C et.al (eds) (2002) Dead and Their Possessions: Repatriation in Principle, Policy and Practice. London and New York: Routledge.

Fontaine J and Harries J (2013) The vitality and efficacy of human substances. Critical African Studies 5: 115-126. 
Förster L et al. (eds) (2018) Provenienzforschung zu ethnografischen Sammlungen der Kolonialzeit. Berlin: Humboldt Universität.

Grabowski J (2013) Hunt for the Jews: Betrayal and Murder in German-Occupied Poland. Bloomington and Indianapolis: Indiana University Press.

Grabowski J (2018) Powiat węgrowski. In: Engelking B and Grabowski J (eds) Dalej jest noc. Losy Żydów w wybranych powiatach okupowanej Polski. Warszawa: Stowarzyszenie Centrum Badań nad Zagładą Żydów, pp. 383-544.

Grabowski J and Libionka D (eds) (2014) Klucze i kasa. O mieniu żydowskim w Polsce pod okupacja niemiecka $i$ we wczesnych latach powojennych 1939-1950. Warszawa: Stowarzyszenie Centrum Badań nad Zagładą Żydów.

Gross JT and Grudzińska Gross I (2012) Golden Harvest: Events at the Periphery of the Holocaust. Oxford: Oxford University Press.

Grosz E (2005) Time Travels: Feminism, Nature, Power. Durham and London: Duke University Press.

Haraway D (1991) Simians, Cyborgs, and Women: The Reinvention of Nature. New York: Routledge.

Harrison S (2012) Dark Trophies: Hunting and the Enemy Body in Modern War. Oxford and New York: Berghahn Books.

Kaplan Sommer A (2018) Home truths about Holocaust turn popular Lithuanian writer into public enemy No.1. Haaretz, 4 February. Available at: https://www.haaretz.com/worldnews/europe/lithuanian-writer-refuses-to-stay-silent-on-country-s-part-in-shoah-1.5786267 (accessed 3 December 2018).

Keenan T and Weizman E (2012) Mengele's Skull: The Advent of Forensic Aesthetics. Berlin: Sternberg Press.

Klinger JE (2017) When so few traces remain. Les Cahiers Sirice 19(2): 93-104.

Krawczyk M (2014) The Effect and Legal Status of Jewish Property in Post-War Poland on Polish-Jewish Relations. In: Tych F and Adamczyk-Grabowska M (eds) Jewish Presence in Absence: The Aftermath of the Holocaust in Poland, 1944-2010. Jerusalem: Yad Vashem, pp. 791-846.

Kreuzmüller Ch and Zatlin J (eds) (2020) Dispossession: Plundering German Jewry, 19331953. Ann Arbor: The University of Michigan Press. 
Krzyżanowski $Ł$ (2014) 'Chcielibyśmy, by ten dom nie pozostał w obcych rękach'. Sądowa restytucja prywatnego mienia żydowskiego w Polsce na przykładzie Radomia i Kalisza 19451948. In: Grabowski J and Libionka D (eds) (2014) Klucze i kasa. O mieniu żydowskim w Polsce pod okupacja niemiecka $i$ we wczesnych latach powojennych 1939-1950. Warszawa: Stowarzyszenie Centrum Badań nad Zagładą Żydów, pp. 575-607.

Lis D (ed) (2011) Wokót 'Złotych żniw'. Debata o książce Jana Tomasza Grossa i Ireny Grudzińskiej-Gross. Kraków: Znak.

Matyjaszek K (2019) Produkcja przestrzeni żydowskiej $w$ dawnej $i$ wspótczesnej Polsce. Kraków: Universitas.

Olszewski M and Litka P (2011) Żółte. Tygodnik Powszechny, 11 January. Available at: https://www.tygodnikpowszechny.pl/zolte-140539 (accessed 3 March 2019).

Perz (2012) Die Verwertung des Opfergoldes aus den Vernichtungslagern der 'Aktion Reinhard'. In: Forschungen zum Nationalsozialismus und Dessen Nachwirkungen in Osterreich, Wien: Dokumentationsarchiv des österreichischen Widerstandes, pp. 131-153.

Plato (1997) The Complete Works of Plato, Indianapolis: Hackett.

Renshaw L (2011) Exhuming Loss: Memory, Materiality and Mass Graves of the Spanish Civil War, London and New York: Routledge.

Reszka P (2019) Płuczki. Poszukiwacze Żydowskiego Złota. Warszawa: Wydawnictwo Agora. Rusiniak M (2008) Obóz Zagłady w Treblinka II w pamięci społecznej (1943-89). Warszawa: Wydawnictwo Neriton.

Sendyka R (2019) Moving remains: Necroperformace and necropolitics of non-sites of memory. Conference presentation, Memory Studies Association, Madrid, 25-28 June.

Shallcross B (2011) The Holocaust Object in Polish and Polish-Jewish Culture. Bloomington: Indiana University Press.

Skibińska A (2014) Problem rewindykacji żydowskich nieruchomości w latach 1945-1950. Zagadnienia ogólne i szczegółowe (na przykładzie Szcczebrzeszyna). In: Grabowski J and Libionka D (eds) (2014) Klucze i kasa. O mieniu żydowskim w Polsce pod okupacją niemiecka $i$ we wczesnych latach powojennych 1939-1950. Warszawa: Stowarzyszenie Centrum Badań nad Zagładą Żydów, pp. 
Skibińska A (2018) Powiat biłgorajski. In: Engelking B and Grabowski J (eds) Dalej jest noc. Losy Żydów w wybranych powiatach okupowanej Polski. Warszawa: Stowarzyszenie Centrum Badań nad Zagładą Żydów, pp. 191-380.

Strzelecki A (1990) The plunder of victims and their corpses. In: Gutman Y and Berenbaum M (eds) Anatomy of the Auschwitz Death Camp. Bloomington, Indianapolis: Indiana University Press, pp. 246-269.

Sturdy Colls C (2018) Holocaust victims, Jewish law and the ethics of archaeological investigations. Accessing Campscapes 3: 32-41.

Sztandar Ludu (1946) Hiena cmentarna spod Treblinki gromadziła złoto i pierścionki z grobów męczenników. Sztandar Ludu, November 10, 308(540), p. 4.

Vanagaite R and Zuroff E (2017) Nasi. Podróżując z wrogiem. Czarna Owca: Warszawa.

Wagner SE (2014) A curious trade: the recovery and repatriation of U.S. Missing in Action from the Vietnam War. Comparative Studies in Society and History 57(1): 160-190.

Woods A (2018) Funeral home owners allegedly paid for trip to Disney with corpses' teeth. New York Post, 12 January. Available at: https://nypost.com/2018/01/12/funeral-home-ownersallegedly-paid-for-trip-to-disney-with-corpses-teeth/ (accessed 3 March 2018).

Zawodna M (2011) O porządkowaniu poobozowego świata. Sposoby postępowania ze szczątkami ludzkimi na terenach byłego KL Auschwitz-Birkenau od momentu ostatecznej likwidacji obozu do powstania muzeum. Zagłada Żydów. Studia i materiały 8, pp. 145-175. 